\title{
UWARUNKOWANIA ZEWNĘTRZNE BUDOWY POTENCJAŁU KONKURENCYJNEGO TAJEMNICZYCH MISTRZÓW POLSKIEJ GOSPODARKI
}

Zarys treści: Rozważania prowadzone w niniejszym artykule dotyczą specyficznej grupy przedsiębiorstw, jakimi są polscy tajemniczy mistrzowie, a zatem firm unikających rozgłosu, a jednocześnie zajmujących czołowe pozycje na rynkach europejskich czy też światowych. W publikacji zaprezentowano fragment wyników przeprowadzonych badań nad polskimi tajemniczymi mistrzami. Celem artykułu jest ukazanie uwarunkowań zewnętrznych, mających największy wpływ na budowę potencjału konkurencyjnego polskich tajemniczych mistrzów. Niezwykle ważne wydaje się dostrzeżenie oddziaływania czynników makrootoczenia na potencjał konkurencyjny tej godnej naśladowania grupy przedsiębiorstw.

Słow a kluczowe: polscy tajemniczy mistrzowie; potencjał konkurencyjny; uwarunkowania zewnętrzne

Klasyfikacja JEL: L22

* Adres do korespondencji: Dorota Grego-Planer, Uniwersytet Mikołaja Kopernika w Toruniu, Wydział Nauk Ekonomicznych i Zarządzania, Katedra Zarządzania Przedsiębiorstwem, ul. Gagarina 13a, 87-100 Toruń, e-mail: dgp@econ.umk.pl. 


\section{WSTĘP}

Tajemniczy mistrzowie współczesnej gospodarki to grupa przedsiębiorstw unikająca wielkiego rozgłosu, a jednocześnie zajmująca czołowe pozycje na rynkach globalnych. Zgodnie z koncepcją H. Simona za tajemniczego mistrza uznaje się przedsiębiorstwo, które zajmuje pierwsze, drugie lub trzecie miejsce na rynku globalnym albo pierwsze miejsce na swoim kontynencie, osiąga przychody poniżej 3 miliardów euro, ma niski poziom obecności w świadomości publicznej - anonimowość [Simon, Dietl, 2009, s. 35].

Autorka w latach 2010-2013 analizowała działalność polskich tajemniczych mistrzów. Definicję polskich ukrytych liderów dostosowano do uwarunkowań polskich, zdając sobie sprawę z faktu, że polskie przedsiębiorstwa nie są jeszcze tak globalnymi firmami, jak zagraniczni tajemniczy mistrzowie. Ich cechy charakterystyczne i strategia działania są bardzo zbliżone do światowych ukrytych liderów zidentyfikowanych przez H. Simona, jednakże swoją światową ekspansję polscy TM rozpoczęli z reguły dopiero po 1989 roku.

Zgodnie z definicją polski tajemniczy mistrz to firma, która:

- zajmuje pierwsze, drugie lub trzecie miejsce na rynku europejskim oraz jest liderem na rynku polskim,

- osiąga przychody poniżej 3 mld euro,

- jest nisko obecna w świadomości publicznej (anonimowość).

Właśnie pozostawanie w cieniu, a zarazem osiąganie pozycji liderów przykuwa największą uwagę i zmusza do formułowania wielu pytań. Warto bowiem zastanowić się nad tym, jak istotny w osiągnięciu pozycji europejskiego czy też światowego lidera okazał się potencjał konkurencyjny i idąc krok dalej, jakie uwarunkowania zewnętrzne oddziałują na ten potencjał w największym stopniu.

W niniejszym artykule zaprezentowano fragment wyników przeprowadzonych badań ${ }^{1}$ nad polskimi tajemniczymi mistrzami. Celem artykułu jest

1 Proces badawczy obejmował następujące etapy:

- badanie główne, w którym dokonano pomiaru sondażowego pośredniego z wykorzystaniem metody wywiadu telefonicznego,

- badanie uzupełniające, w którym posłużono się metodą badania eksperckiego w wersji korespondencyjnej. 
ukazanie uwarunkowań zewnętrznych mających największy wpływ na budowę potencjału konkurencyjnego polskich tajemniczych mistrzów.

\section{UWARUNKOWANIA POTENCJAŁU KONKURENCYJNEGO W ŚWIETLE TEORII}

Konkurencyjność jest zjawiskiem bardzo obszernym, a samo jej zdefiniowanie wynika z różnorodnych poglądów autorów. Dlatego ważne okazuje się przyjęcie określonej koncepcji konkurencyjności i zidentyfikowanie jej elementów składowych. Konkurencyjność przedsiębiorstwa może być postrzegana jako system składający się z mniejszych podsystemów, z których każdy przyczynia się do powodzenia przedsiębiorstwa w konkurencyjnym otoczeniu. Propozycje ujęcia konkurencyjności w postaci modelu prezentuje między innymi M. J. Stankiewicz, który konkurencyjność traktuje jako system złożony z czterech elementów. Podsystemami, a zarazem elementami strukturalnymi systemu „konkurencyjność przedsiębiorstwa”, są [Stankiewicz, 2002, s. 86-89]:

- potencjał konkurencyjności,

- przewaga konkurencyjna,

- instrumenty konkurowania,

- pozycja konkurencyjna.

Niewątpliwie najważniejszym elementem systemu z punktu widzenia prowadzonej tu analizy jest potencjał konkurencyjności. Jak pisze B. Godziszewski, jest on ,kategorią o zasadniczym znaczeniu dla skutecznego konkurowania w dhugim okresie czasu" [Godziszewski, 1999, s. 123]. Potencjał konkurencyjności przedsiębiorstwa traktowany jest jako zbiór zasobów o charakterze zarówno materialnym, jak i niematerialnym, którymi przedsiębiorstwo powinno dysponować, aby móc funkcjonować na arenie konkurencyjnej [Stankiewicz, 2002, s. 89]. Aby skutecznie konkurować, należy bardzo dokładnie zidentyfikować składniki potencjału konkurencyjności przedsiębiorstwa, czyli zasoby, których charakter i stan będą przesądzały o wymiarach przewagi konkurencyjnej². Samo posiadanie zasobów, traktowanych jako aktywa będące $w$ dyspozycji przedsiębiorstwa, nie jest zatem wystarczające. O konkurencyjności decydować będzie nie tyle ilość zasobów, co ich jakość i umiejętność odpowiedniego wykorzystania.

2 Mowa tu o podstawowych wymiarach przewagi konkurencyjnej, czyli rodzaju, wielkości oraz jej trwałości. 
Choć bezpośrednią podstawą potencjału konkurencyjnego są zasoby, stanowiąc jego uwarunkowania wewnętrzne, to jednak również otoczenie zewnętrzne wpływa na jego budowę, determinując pożądane cechy tegoż potencjału. To właśnie uwarunkowania zewnętrzne, kreowane przez szeroko pojęte otoczenie, są przedmiotem analizy niniejszego artykułu.

Andrzej K. Koźmiński otoczeniem nazywa wszystko to, co znajduje się na zewnątrz organizacji, poza jej granicami, a jednocześnie oddziałuje na nią [Koźmiński, 2005 s. 33]. L. A. Digman pisał, że otoczenie to pewien system sił tkwiących na zewnątrz organizacji, które wywierają wpływ na jej funkcjonowanie obecnie i w przyszłości, oraz będących pod jej wpływem [Digman, 1990, s. 93]. Bez względu na to, jaką definicję otoczenia się przywoła, na pewno w każdej podkreśla się jego wpływ na działalność przedsiębiorstw. W obecnej dobie „świata bez granic”, gdzie ciężko nadążyć za postępem technologicznym i zachodzącymi zmianami, jeszcze baczniej należy owo otoczenie obserwować i ściśle analizować. Stopień otwartości przedsiębiorstwa na otoczenie będzie zatem zależeć, w zdecydowanym zakresie, od zmienności i złożoności czynników tegoż otoczenia [Bielski, 2001, s. 127].

W literaturze przedmiotu spotyka się różne podziały otoczenia. Najbardziej ogólny dzieli uwarunkowania zewnętrzne na makrootoczenie, inaczej dalsze, i mikrootoczenie nazywane bliższym, sektorowym czy też konkurencyjnym.

Makrootoczenie to według Philipa Kotlera miejsce, w którym każde przedsiębiorstwo powinno rozpoczynać poszukiwania swych rynkowych możliwości, jak i potencjalnych zagrożeń. Jak pisze autor, na makrootoczenie składają się „wszystkie jednostki, organizacje i czynniki, które wpływają na działalność przedsiębiorstwa i jego rezultaty" [Kotler, 1999, s. 157]. Elementy makrootoczenia, czyli otoczenia dalszego, mogą zatem mieć na przedsiębiorstwa tak stymulujący, jak i hamujący wpływ poprzez stwarzanie zarówno szans, jak i zagrożeń dla ich rozwoju. Ma to swoje odzwierciedlenie również w całym procesie konkurowania. Pewne czynniki makrootoczenia wpływać będą na kształtowanie się potencjału konkurencyjnego, dalej na przewagę konkurencyjną przedsiębiorstw pozytywnie, a pewne negatywnie. Przedsiębiorstwa nie są jednak w stanie kontrolować ani kształtować tych czynników.

Uwarunkowania makrootoczenia złożone z poszczególnych jego czynników podzielić można na kilka grup:

- uwarunkowania ekonomiczne,

- uwarunkowania polityczno-prawne,

- uwarunkowania socjokulturowe, 
- uwarunkowania demograficzne,

- uwarunkowania międzynarodowe,

- uwarunkowania techniczne,

- uwarunkowania geograficzne.

W niniejszym artykule zaprezentowano wpływ uwarunkowań makro na budowę potencjału konkurencyjnego polskich tajemniczych mistrzów.

\section{UWARUNKOWANIA ZEWNĘTRZNE BUDOWY POTENCJAŁU KONKURENCYJNEGO TAJEMNICZYCH MISTRZÓW POLSKIEJ GOSPODARKI - WYNIKI BADAŃ}

Analizę uwarunkowań zewnętrznych oddziałujących na budowę potencjału konkurencyjnego polskich tajemniczych mistrzów przeprowadzono na podstawie opisanego podziału na makro- i mikrootoczenie, inaczej otoczenie sektorowe. Korzystając jednocześnie z literatury przedmiotu, a także z dostępnych badań empirycznych [zob. np. Zastempowski, 2004, s. 149-167], stworzono listę czynników zewnętrznych mogących stymulować bądź też hamować budowę potencjału konkurencyjnego przedsiębiorstw. Zidentyfikowane czynniki przypisano następnie do wymienionych wcześniej grup uwarunkowań - makro. Należy oczywiście wspomnieć, że analizę czynników zewnętrznych przeprowadzono, mając pełną świadomość, iż ich lista nie jest pełna i z pewnością mogłaby zostać uzupełniona o szereg innych, równie ważnych pod względem badawczym. Niemniej jednak wydaje się, że jest ona na tyle obszerna, że można na jej podstawie podjąć próbę zaprezentowania występujących w Polsce warunków rozwoju potencjału konkurencyjnego polskich tajemniczych mistrzów.

Podczas badania ankietowego respondenci zostali poproszeni o ocenę stopnia, w jakim dany czynnik zewnętrzny wpływa na budowanie ich potencjału konkurencyjnego. Polscy tajemniczy mistrzowie w ocenie stopnia oddziaływania każdego z czynników kierowali się pięciostopniową skalą: 5 - zdecydowanie pozytywny wpływ, 4 - raczej pozytywny wpływ, 3 brak wpływu, 2 - raczej negatywny wpływ, 1 - zdecydowanie negatywny wpływ ${ }^{3}$. Aby ustalić ostateczny kierunek siły wpływu każdego z oce-

3 Dokonując wyboru skali oceny wpływu poszczególnych składników na przewagę konkurencyjną, wykorzystano podejście proponowane m.in. przez następujących autorów: Karaszewski, 2004, s. 321; Sudolska, 2011, s. 232-233. 
nianych czynników, obliczono średnią arytmetyczną ważoną i nazwano ją współczynnikiem oddziaływania $\mathrm{S}^{5}$. Dla jeszcze bardziej wyraźnego ukazania stopnia oddziaływania poszczególnych czynników na budowę potencjału konkurencyjnego polskich tajemniczych mistrzów zastosowano drugą miarę ważności, jaką jest procentowy udział wskazań przedsiębiorstw na dany element.

W tabelach 1--6 zaprezentowano szczegółowe wyniki dotyczącewpływu analizowanych czynników na budowę potencjału konkurencyjnego polskich tajemniczych mistrzów. Objęte analizą czynniki zewnętrzne uszeregowane zostały w ramach poszczególnych grup uwarunkowań w sposób malejący. W tabelach oprócz wartości współczynnika oddziaływania S, określonego dla każdego czynnika, zaprezentowano także kierunek jego wpływu. Przy czym przyjęto, że jeżeli dany czynnik uzyskał ocenę poniżej 3 (w przyjętej pięciostopniowej skali), to jego wpływ na budowę przewagi konkurencyjnej jest negatywny, natomiast powyżej 3 - pozytywny ${ }^{6}$.

\section{OCENA CHARAKTERU I SIEY WPŁYWU CZYNNIKÓW MAKROOTOCZENIA}

Pierwszą poddaną analizie grupą czynników zewnętrznych były uwarunkowania międzynarodowowe. Wśród nich najważniejsze okazały się dwa czynniki $(S=4,29)$, a mianowicie integracja z Unią Europejską oraz

4 Ogólna postać średniej arytmetycznej ważonej jest następująca:

$\overline{\mathrm{x}}=\mathrm{x}_{1} \mathrm{n}_{1}+\mathrm{x}_{2} \mathrm{n}_{2}+\ldots+\mathrm{x}_{\mathrm{n}} \mathrm{n}_{\mathrm{m}} / \mathrm{n}_{1}+\mathrm{n}_{2}+\ldots+\mathrm{n}_{\mathrm{m}}=\sum \mathrm{x}_{\mathrm{i}} \mathrm{n}_{\mathrm{i}} / \mathrm{N}$

gdzie: $n_{i}$ - liczebność, częstość, z jaką występuje $i$-ta wartość zmiennej $x$. Zob. Krzysztofiak, Urbanek, 1975, s. 167. Zastosowana w badaniu skala jest skalą porządkową, jednakże zdecydowano się zastosować ją w niniejszych badaniach, zwracając uwagę na stwierdzenia S. Kaczmarczyka, który pisze, że ,zdarza się bardzo często w badaniach marketingowych, że skale porządkowe traktuje się jako przedziałowe, czyli próbuje się mierzyć cechy, które nie mają jednostki miary. Przy konstruowaniu tych skal zakłada się, że różnice między sąsiednimi klasami są równe. [...] Wielu badaczy traktuje dane uzyskane z pomiaru porządkowego jako dane z pomiaru przedziałowego i stosuje wówczas metody statystyczne przeznaczone do analizy danych uzyskanych z pomiaru przedziałowego". Zob. Kaczmarczyk, 2002, s. 91.

5 Koncepcję współczynnika oddziaływania S zaczerpnięto od W. Karaszewskiego. Zob. Karaszewski, 2001, s. 304-305.

6 Jeżeli dany czynnik uzyskał ocenę 1 lub 2, jego wpływ potraktowano jako negatywny, jeżeli 3 - jako neutralny, tzn. brak wpływu, natomiast 4 lub 5 - jako pozytywny. 
procesy globalizacyjne. Wynik ten nie dziwi, zwłaszcza gdy ma się na uwadze zakres działalności tajemniczych mistrzów. Z samej definicji polski tajemniczy mistrz to lider krajowy, ale także podmiot zajmujący jedną z trzech pierwszych pozycji na rynku europejskim, a zatem jego działalność znacznie wybiega poza granice macierzystego kraju. Wejście Polski do Unii Europejskiej i otwarcie zagranicznych rynków stało się dla nich ogromną szansą rozwoju. Warto wskazać, że badania były prowadzone, gdy Polska już od siedmiu lat była członkiem Wspólnoty Europejskiej, a zatem przedsiębiorstwa te miały czas, aby pozytywnie wykorzystać integrację. Nieco mniej istotne, aczkolwiek jeszcze o pozytywnym wpływie na potencjał konkurencyjny respondentów, okazało się odrodzenie rynków „wschodnich" $(S=3,83)$. Czynnik ten miał dość duże znaczenie dla tych tajemniczych mistrzów, którzy eksportują bądź też prowadzą działalność na rynkach wschodnich. Dla $34,1 \%$ nie miał on żadnego znaczenia. Inne wyniki kształtują się przy dwóch ostatnich czynnikach uwarunkowań międzynarodowych. Siła konkurencji na rynkach międzynarodowych $(S=3,37)$ oraz restrykcje, sankcje i inne formy ochrony rynków narodowych $(S=3,22)$ przez część respondentów ocenione zostały jako czynniki negatywnie oddziałujące na ich potencjał konkurencyjny. Być może nieznaczna liczba polskich tajemniczych mistrzów ma jeszcze dość spore problemy z silną konkurencją, zwłaszcza na rynkach innych kontynentów. Należy pamiętać, że większość polskich ukrytych liderów to firmy stosunkowo młode, które jeszcze nie zdążyły stać się prawdziwie globalnymi graczami. Warto jednak dodać, że dla prawie 50\% badanych firm problem silnej konkurencji na międzynarodowych rynkach w ogóle nie istnieje. Szczegółowe dane przedstawia tabela 1.1

W ramach uwarunkowań ekonomicznych analizie poddano dziesięć czynników. Respondenci uznali, że największy pozytywny wpływ na ich potencjał konkurencyjny ma koniunktura gospodarcza $(S=4,27)$, a zaraz po niej umiędzynarodowienie polskiej gospodarki $(S=4,17)$. Również stabilność kursu walutowego przez ponad 85\% polskich tajemniczych mistrzów uznana została za czynnik pozytywnie wpływający na budowę ich potencjału. Odpowiedź ta jest dość zrozumiała. Przy działalności międzynarodowej, a przecież taką odznaczają się badane przedsiębiorstwa, stabilność kursu jest bardzo istotna i zdecydowanie ułatwia wymianę międzynarodową. Nieco mniejsze, lecz pozytywne znaczenie mają: dostęp do rynku kapitałowego $(S=3,68)$, wysokość inflacji $(S=3,56)$, decyzje Rady Polityki Pieniężnej wobec stóp procentowych oraz poziom inwestycji zagranicznych $(S=3,49)$. Bliskie neutralnego wpływu są takie czynniki, jak poziom 
bezrobocia w kraju $(S=3,24)$ czy też jego poziom w regionie funkcjonowania firmy $(S=3,02)$. Koszty energii - ceny ropy naftowej przez ponad $46 \%$ respondentów zostały ocenione jako hamujące budowę ich potencjału konkurencyjnego, natomiast przez 39\% jako niewywierające jakiegokolwiek wpływu. Negatywny wpływ zaznaczyły przede wszystkim te przedsiębiorstwa, które z powodu wysokich cen ropy ponoszą bardzo duże koszty transportu. Taka sytuacja z pewnością wpływa negatywnie na ich rozwój. Uzyskane wyniki w tym obszarze zawarto w tabeli 2.

Tabela 1. Uwarunkowania międzynarodowe i ich wpływ na budowę potencjału konkurencyjnego polskich tajemniczych mistrzów

\begin{tabular}{|c|c|c|c|c|c|}
\hline \multirow{3}{*}{ Lp. } & \multirow{3}{*}{ Uwarunkowania międzynarodowe } & \multirow{3}{*}{$\begin{array}{c}\text { Siła oddziaływania } \\
\text { poszczególnych } \\
\text { składników - } \\
\text { S }\end{array}$} & \multirow{2}{*}{\multicolumn{3}{|c|}{$\begin{array}{c}\begin{array}{c}\text { Kierunek } \\
\text { oddziaływania }\end{array} \\
\begin{array}{c}\text { Udział \% } \\
\text { liczby wskazań }\end{array}\end{array}$}} \\
\hline & & & & & \\
\hline & & & neg. & bw. & poz. \\
\hline 1 & Integracja z Unią Europejską & 4,29 & 0,0 & 4,9 & 95,1 \\
\hline 2 & Procesy globalizacyjne & 4,29 & 2,4 & 7,3 & 90,3 \\
\hline 3 & Odrodzenie rynków „wschodnich” & 3,83 & 0,0 & 34,1 & 65,9 \\
\hline 4 & $\begin{array}{l}\text { Siła konkurencji na rynkach } \\
\text { międzynarodowych }\end{array}$ & 3,37 & 12,2 & 48,8 & 39,0 \\
\hline 5 & $\begin{array}{l}\text { Restrykcje, sankcje i inne formy } \\
\text { ochrony rynków narodowych }\end{array}$ & 3,22 & 14,6 & 56,1 & 29,3 \\
\hline & Współczynnik S - średnio & 3,80 & & & \\
\hline
\end{tabular}

Objaśnienia: neg. - negatywny, bw. - brak wpływu, poz. - pozytywny

Źródło: opracowanie własne na podstawie przeprowadzonych badań empirycznych. 
Tabela 2. Uwarunkowania ekonomiczne i ich wpływ na budowę potencjału konkurencyjnego polskich tajemniczych mistrzów

\begin{tabular}{|c|c|c|c|c|c|}
\hline \multirow{3}{*}{ Lp. } & \multirow{3}{*}{ Uwarunkowania ekonomiczne } & \multirow{3}{*}{$\begin{array}{l}\text { Siła oddziaływania } \\
\text { poszczególnych } \\
\text { składników - } \\
\text { S }\end{array}$} & \multirow{2}{*}{\multicolumn{3}{|c|}{$\begin{array}{c}\text { Kierunek } \\
\text { oddziaływania } \\
\text { Udział \% liczby } \\
\text { wskazań }\end{array}$}} \\
\hline & & & & & \\
\hline & & & neg. & bw. & poz. \\
\hline 1 & Koniunktura gospodarcza & 4,27 & 7,3 & 7,3 & 85,4 \\
\hline 2 & $\begin{array}{l}\text { Umiędzynarodowienie polskiej } \\
\text { gospodarki }\end{array}$ & 4,17 & 2,4 & 9,7 & 87,9 \\
\hline 3 & Stabilność kursu walutowego & 4,15 & 9,7 & 4,9 & 85,4 \\
\hline 4 & $\begin{array}{l}\text { Dostęp do rynku kapitałowego } \\
\text { (Giełda Papierów Wartościowych) }\end{array}$ & 3,68 & 0,0 & 51,2 & 48,8 \\
\hline 5 & Wysokość inflacji & 3,56 & 7,3 & 41,5 & 51,2 \\
\hline 6 & $\begin{array}{l}\text { Decyzje Rady Polityki Pieniężnej } \\
\text { wobec stóp procentowych }\end{array}$ & 3,49 & 7,0 & 13,0 & 21,0 \\
\hline 7 & Poziom inwestycji zagranicznych & 3,49 & 1,0 & 21,0 & 19,0 \\
\hline 8 & Poziom bezrobocia w kraju & 3,24 & 1,0 & 32,0 & 8,0 \\
\hline 9 & $\begin{array}{l}\text { Poziom bezrobocia w regionie } \\
\text { funkcjonowania firmy }\end{array}$ & 3,02 & 3,0 & 35,0 & 3,0 \\
\hline 10 & $\begin{array}{l}\text { Koszty energii (ceny ropy nafto- } \\
\text { wej) }\end{array}$ & 2,66 & 19,0 & 16,0 & 6,0 \\
\hline & Współczynnik S - średnio & 3,57 & & & \\
\hline
\end{tabular}

Objaśnienia: neg. - negatywny, bw. - brak wpływu, poz. - pozytywny

Źródło: opracowanie własne na podstawie przeprowadzonych badań empirycznych.

Wśród makroekonomicznych czynników stymulujących lub też hamujących budowę potencjału konkurencyjnego polskich tajemniczych mistrzów wyróżniono również czynniki uwarunkowań socjokulturowych i demograficznych. Całą grupę oceniono jako nieznacznie pozytywnie oddziałującą na omawiany potencjał. Jednakże najbardziej istotny okazał się styl życia oraz poziom wykształcenia ludności ze współczynnikami S równymi kolejno 3,93 i 3,73. Mobilność siły roboczej $(S=3,63)$ dla połowy respondentów ma stymulujący wpływ na budowę ich potencjału konkurencyjnego. Wyraźne znaczenie czynnik ten ma w tych przed- 
siębiorstwach, które zmuszone są oddelegowywać swoją kadrę do filii zagranicznych, co często wiąże się ze zmianą miejsca zamieszkania. Etyka pracy $(S=3,44)$ to kolejny dość istotny czynnik, natomiast migracje ludności $(S=3,27)$ czy też wierzenia, wartości i normy zachowań $(S=3,22)$ dla większości polskich tajemniczych mistrzów nie mają żadnego znaczenia z punktu widzenia ich konkurencyjność. Szczegółowe dane przedstawia tabela 3 .

Tabela 3. Uwarunkowania socjokulturowe i demograficzne oraz ich wpływ na budowę potencjału konkurencyjnego polskich tajemniczych mistrzów

\begin{tabular}{|c|c|c|c|c|c|}
\hline \multirow{3}{*}{ Lp. } & \multirow{3}{*}{$\begin{array}{l}\text { Uwarunkowania socjokulturowe } \\
\text { i demograficzne }\end{array}$} & \multirow{3}{*}{$\begin{array}{c}\text { Siła oddziaływania } \\
\text { poszczególnych } \\
\text { składników - } \\
\text { S }\end{array}$} & \multirow{2}{*}{\multicolumn{3}{|c|}{$\begin{array}{c}\begin{array}{c}\text { Kierunek } \\
\text { oddziaływania }\end{array} \\
\begin{array}{c}\text { Udział \% liczby } \\
\text { wskazań }\end{array}\end{array}$}} \\
\hline & & & & & \\
\hline & & & neg. & bw. & poz. \\
\hline 1 & Styl życia & 3,93 & 0,0 & 22,0 & 78,0 \\
\hline 2 & Poziom wykształcenia ludności & 3,73 & 0,0 & 36,6 & 63,4 \\
\hline 3 & Mobilność siły roboczej & 3,63 & 0,0 & 48,8 & 51,2 \\
\hline 4 & Etyka pracy & 3,44 & 2,4 & 53,7 & 43,9 \\
\hline 5 & Migracje ludności & 3,27 & 2,4 & 70,7 & 26,9 \\
\hline 6 & $\begin{array}{l}\text { Wierzenia, wartości, normy zachowań } \\
\text { (etyczne, moralne) }\end{array}$ & 3,22 & 0,0 & 80,5 & 19,5 \\
\hline & Współczynnik S - średnio & 3,54 & & & \\
\hline
\end{tabular}

Objaśnienia: neg. - negatywny, bw. - brak wpływu, poz. - pozytywny

Źródło: opracowanie własne na podstawie przeprowadzonych badań empirycznych.

Kolejną z analizowanych grup makrootoczenia były uwarunkowania technologiczne. Spośród wszystkich czynników respondenci najwyżej ocenili szybkość transferu techniki i technologii. Dla $61 \%$ czynnik ten pozytywnie wpływa na budowę ich potencjału konkurencyjnego, co z resztą zgodne jest $\mathrm{z}$ faktem, że polscy tajemniczy mistrzowie opierają swoją działalność na bardzo zaawansowanych technologiach, których transfer jest niezwykle istotny. Na kolejnych miejscach znalazły się takie czynniki, jak tempo pojawiania się nowych wynalazków $(S=3,59)$ oraz rządowa polityka dotycząca badań i rozwoju $(S=3,56)$. Obydwa wymienione czyn- 
niki przez około połowę badanych ocenione są pozytywnie, a przez drugą część neutralnie. Na uwagę zasługują jednak dwa ostatnie czynniki uwarunkowań technologicznych, a mianowicie ochrona patentów i wzorów użytkowych $(S=3,20)$ oraz procedury patentowe $(S=3,17)$. Jak wcześniej zostało wspomniane, tajemniczy mistrzowie to „właściciele patentów”. Zatem istotne jest to, że spora część badanych firm zdecydowanie narzeka na ich ochronę i na procedury patentowe. Czynniki te przez ponad 20\% respondentów zostały uznane za negatywnie oddziałujące na ich potencjał konkurencyjny. To wyraźny znak dla polskiego rządu. Skoro Ci, którzy patentują swoje niejednokrotnie bardzo innowacyjne wynalazki, zgłaszają istotne problemy związane z tym zjawiskiem, to należałoby coś zmienić. Sposób, w jaki poddane badaniom przedsiębiorstwa postrzegają oddziaływanie czynników należących do tej grupy uwarunkowań, zaprezentowany został w tabeli 4.

Tabela 4. Uwarunkowania technologiczne i ich wpływ na budowę potencjału konkurencyjnego polskich tajemniczych mistrzów

\begin{tabular}{|c|c|c|c|c|c|}
\hline \multirow{3}{*}{ Lp. } & \multirow{3}{*}{ Uwarunkowania technologiczne } & \multirow{3}{*}{$\begin{array}{c}\text { Siła oddziaływa- } \\
\text { nia poszczegól- } \\
\text { nych składników } \\
\overline{-} \\
\text { S }\end{array}$} & \multirow{2}{*}{\multicolumn{3}{|c|}{$\begin{array}{c}\text { Kierunek } \\
\text { oddziaływania } \\
\begin{array}{c}\text { Udział \% liczby } \\
\text { wskazań }\end{array}\end{array}$}} \\
\hline & & & & & \\
\hline & & & neg. & bw. & poz. \\
\hline 1 & $\begin{array}{l}\text { Szybkość transferu techniki i techno- } \\
\text { logii }\end{array}$ & 3,66 & 2,4 & 36,6 & 61,0 \\
\hline 2 & $\begin{array}{l}\text { Tempo pojawiania się nowych wyna- } \\
\text { lazków }\end{array}$ & 3,59 & 0,0 & 46,3 & 53,7 \\
\hline 3 & $\begin{array}{l}\text { Rządowa polityka dotycząca badań } \\
\text { i rozwoju }\end{array}$ & 3,56 & 0,0 & 51,2 & 48,8 \\
\hline 4 & $\begin{array}{l}\text { Ochrona patentów i wzorów użytko- } \\
\text { wych }\end{array}$ & 3,20 & 24,4 & 39,0 & 36,6 \\
\hline 5 & Procedury patentowe & 3,17 & 19,5 & 43,9 & 36,6 \\
\hline & Współczynnik S - średnio & 3,43 & & & \\
\hline
\end{tabular}

Objaśnienia: neg. - negatywny, bw. - brak wpływu, poz. - pozytywny

Źródło: opracowanie własne na podstawie przeprowadzonych badań empirycznych. 
W ramach uwarunkowań geograficznych analizie poddano cztery czynniki. Położenie geograficzne przedsiębiorstwa $(S=3,41)$ to czynnik o nieznacznie pozytywnym wpływie na budowę potencjału konkurencyjnego polskich tajemniczych mistrzów. Należy jednak wspomnieć, że aż dla prawie 59\% respondentów jest on czynnikiem nieistotnym. Ta odpowiedź nie dziwi. Polscy tajemniczy mistrzowie jasno podkreślają, że nie są związani z jednym miejscem. Ich działalność jest działalnością międzynarodową, obsługują klientów na całym świecie, a odległości nie mają żadnego znaczenia. Dostępność surowców naturalnych $(S=3,34)$, a także stan środowiska naturalnego $(S=3,27)$ to czynniki ocenione przez większość badanych firm jako neutralne z punktu widzenia konkurencyjności. Natomiast, co ważne, stan infrastruktury $(S=3,27)$ przez prawie $30 \%$ respondentów uznany został za czynnik negatywny, zatem hamujący budowę potencjału konkurencyjnego. Szczegółowe wyniki prezentuje tabela 5 .

Tabela 5. Uwarunkowania geograficzne i ich wpływ na budowę potencjału konkurencyjnego polskich tajemniczych mistrzów

\begin{tabular}{|c|c|c|c|c|c|}
\hline \multirow{3}{*}{ Lp. } & \multirow{3}{*}{ Uwarunkowania geograficzne } & \multirow{3}{*}{$\begin{array}{l}\text { Siła oddziały- } \\
\text { wania po- } \\
\text { szczególnych } \\
\text { składników - } \\
\text { S }\end{array}$} & \multirow{2}{*}{\multicolumn{3}{|c|}{$\begin{array}{c}\text { Kierunek } \\
\text { oddziaływania } \\
\begin{array}{c}\text { Udział \% liczby } \\
\text { wskazań }\end{array}\end{array}$}} \\
\hline & & & & & \\
\hline & & & neg. & bw. & poz. \\
\hline 1 & $\begin{array}{l}\text { Położenie geograficzne przedsiębior- } \\
\text { stwa }\end{array}$ & 3,41 & 2,4 & 58,6 & 39,0 \\
\hline 2 & Dostępność surowców naturalnych & 3,34 & 0,0 & 65,9 & 34,1 \\
\hline 3 & Stan infrastruktury & 3,29 & 26,8 & 24,4 & 48,8 \\
\hline 4 & Stan środowiska naturalnego & 3,27 & 0,0 & 78,0 & 22,0 \\
\hline & Współczynnik S - średnio & 3,33 & & & \\
\hline
\end{tabular}

Objaśnienia: neg. - negatywny, bw. - brak wpływu, poz. - pozytywny

Źródło: opracowanie własne na podstawie przeprowadzonych badań empirycznych.

Ostatnią ocenianą grupą uwarunkowań makrootoczenia były uwarunkowania polityczno-prawne. Czynniki tej grupy w większości dotyczyły obowiązującego systemu prawnego, obciążeń podatkowych czy też 
działalności różnorodnych instytucji państwowych. 14 z 16 czynników uwarunkowań polityczno-prawnych zostało uznanych za oddziałujących pozytywnie na budowę potencjału konkurencyjnego polskich tajemniczych mistrzów, jednak oddziaływanie to było umiarkowane bądź też nieznaczne. Respondenci największe znaczenie przypisali polityce proinnowacyjnej $(S=3,71)$. Nie można zapomnieć, że polscy ukryci liderzy to wielcy innowatorzy, a zatem element polityki związany ze zjawiskiem innowacyjności jest dla nich najbardziej istotny. Stabilność przepisów podatkowych i wsparcie finansowe rozwoju sektora MŚP to elementy ocenione na średnim poziomie 3,46. Jednakże ten pierwszy przez $17 \%$ respondentów traktowany jest jako negatywny. Nieco niżej badane przedsiębiorstwa oceniły takie czynniki, jak stabilność prawa i jasność jego reguł $(S=3,41)$, wsparcie instytucjonalne rozwoju sektora MŚP $(S=3,39)$, politykę celną $(S=3,34)$, wysokość ulg podatkowych $(S=3,32)$, politykę antymonopolową $(S=3,29)$, zamówienia rządowe $(S=3,24)$ oraz politykę ochrony środowiska $(S=3,22)$. Wysokość podatków lokalnych, stabilność przepisów administracyjnych oraz wymogi i procedury certyfikacyjne to czynniki uznane przez średnio $80 \%$ polskich tajemniczych mistrzów za neutralne. Wysokość obciążeń podatkowych $(S=3,07)$, pomimo bardzo nieznacznej oceny pozytywnej, przez prawie $32 \%$ badanych firm uznana została za czynnik hamujący budowę ich potencjału konkurencyjnego. W Polsce powszechne jest stanowisko, że obciążenia podatkowe negatywnie wpływają na rozwój wielu przedsiębiorstw. Wpływ dwóch ostatnich spośród szesnastu czynników polityczno-prawnych oceniony został przez większość respondentów jako negatywny. Oddziaływanie związków zawodowych pracowników $(S=2,73)$ nieznacznie negatywnie oceniło $29,3 \%$ badanych, natomiast ponad $68 \%$ wpływ ten określiło jako neutralny. Niepokojący wynik jednak pojawia się przy ostatnim czynniku, jakim jest biurokracja $(S=2,17)$. Aż $73,2 \%$ respondentów twierdzi, że biurokracja hamuje ich potencjał konkurencyjny. Jest to najgorszy wynik wśród wszystkich czynników uwarunkowań makrootoczenia. Wyniki prezentuje tabela 6 . 
Tabela 6. Uwarunkowania polityczno-prawne i ich wpływ na budowę potencjału konkurencyjnego polskich tajemniczych mistrzów

\begin{tabular}{|c|c|c|c|c|c|}
\hline \multirow{3}{*}{ Lp. } & \multirow{3}{*}{ Uwarunkowania polityczno-prawne } & \multirow{3}{*}{$\begin{array}{l}\text { Siła oddzia- } \\
\text { ływania po- } \\
\text { szczególnych } \\
\text { składników - } \\
\text { S }\end{array}$} & \multirow{2}{*}{\multicolumn{3}{|c|}{$\begin{array}{c}\text { Kierunek } \\
\text { oddziaływania } \\
\begin{array}{c}\text { Udział \% liczby } \\
\text { wskazań }\end{array}\end{array}$}} \\
\hline & & & & & \\
\hline & & & neg. & bw. & poz. \\
\hline 1 & Polityka proinnowacyjna & 3,71 & 0,0 & 43,9 & 56,1 \\
\hline 2 & Stabilność przepisów podatkowych & 3,46 & 17,1 & 29,2 & 53,7 \\
\hline 3 & $\begin{array}{l}\text { Wsparcie finansowe rozwoju sektora } \\
\text { MŚP }\end{array}$ & 3,46 & 0,0 & 68,3 & 31,7 \\
\hline 4 & Stabilność prawa i jasność jego reguł & 3,41 & 14,6 & 34,1 & 51,2 \\
\hline 5 & $\begin{array}{l}\text { Wsparcie instytucjonalne rozwoju } \\
\text { sektora MŚP }\end{array}$ & 3,39 & 0,0 & 68,3 & 31,7 \\
\hline 6 & Polityka celna & 3,34 & 0,0 & 65,9 & 34,1 \\
\hline 7 & Wysokość ulg podatkowych & 3,32 & 2,4 & 73,2 & 24,4 \\
\hline 8 & Polityka antymonopolowa & 3,29 & 0,0 & 75,6 & 24,4 \\
\hline 9 & Zamówienia rządowe & 3,24 & 0,0 & 82,9 & 17,1 \\
\hline 10 & Polityka ochrony środowiska & 3,22 & 7,3 & 63,4 & 29,3 \\
\hline 11 & $\begin{array}{l}\text { Wysokość podatków lokalnych } \\
\text { (strefy ekonomiczne) }\end{array}$ & 3,20 & 2,4 & 82,9 & 14,7 \\
\hline 12 & $\begin{array}{l}\text { Stabilność przepisów administracyjnych } \\
\text { (np. certyfikaty, świadectwa wymagane } \\
\text { w imporcie) }\end{array}$ & 3,20 & 4,9 & 75,6 & 19,5 \\
\hline 13. & Wymogi i procedury certyfikacyjne & 3,17 & 7,3 & 78,0 & 14,7 \\
\hline 14 & Wysokość obciążeń podatkowych & 3,07 & 31,7 & 39,0 & 29,3 \\
\hline 15 & $\begin{array}{l}\text { Oddziaływanie związków zawodowych } \\
\text { pracowników }\end{array}$ & 2,73 & 29,3 & 68,3 & 2,4 \\
\hline 16 & Biurokracja & 2,17 & 73,2 & 19,5 & 7,3 \\
\hline & Współczynnik S - średnio & 3,21 & & & \\
\hline
\end{tabular}

Objaśnienia: neg. - negatywny, bw. - brak wpływu, poz. - pozytywny

Źródło: opracowanie własne na podstawie przeprowadzonych badań empirycznych. 


\section{PODSUMOWANIE}

Podsumowując rozważania prowadzone $\mathrm{w}$ niniejszym artykule, należy podkreślić, że uwarunkowania makrootoczenia nie wywierają bardzo istotnego wpływu na budowę potencjału konkurencyjnego polskich tajemniczych mistrzów. Wartości współczynnika S dla wszystkich analizowanych czynników mieściły się w przedziale od 2,17 do 4,29 w przyjętej pięciostopniowej skali, co tym samym świadczy o ich zróżnicowanym wpływie, jednakże wpływie niewielkim bądź umiarkowanym. Uogólnione wyniki dla całego makrootoczenia, jak również dla poszczególnych jego grup prezentuje wykres 1.

Wyniki sugerują, że uwarunkowania makrootoczenia oddziałują na potencjał konkurencyjny badanych przedsiębiorstw w sposób nieznacznie pozytywny $(\mathrm{S}=3,43)$. Najbardziej istotne okazują się uwarunkowania międzynarodowe, ze średnią oceną 3,8 . Na kolejnych miejscach znalazły się uwarunkowania ekonomiczne $(S=3,57)$, socjokulturowe i demograficzne $(S=3,54)$, technologiczne $(S=3,43)$ i geograficzne $(S=3,33)$. Bliskie neutralnego wpływu na budowę potencjału konkurencyjnego polskich tajemniczych mistrzów są uwarunkowania polityczno-prawne $(S=3,21)$.

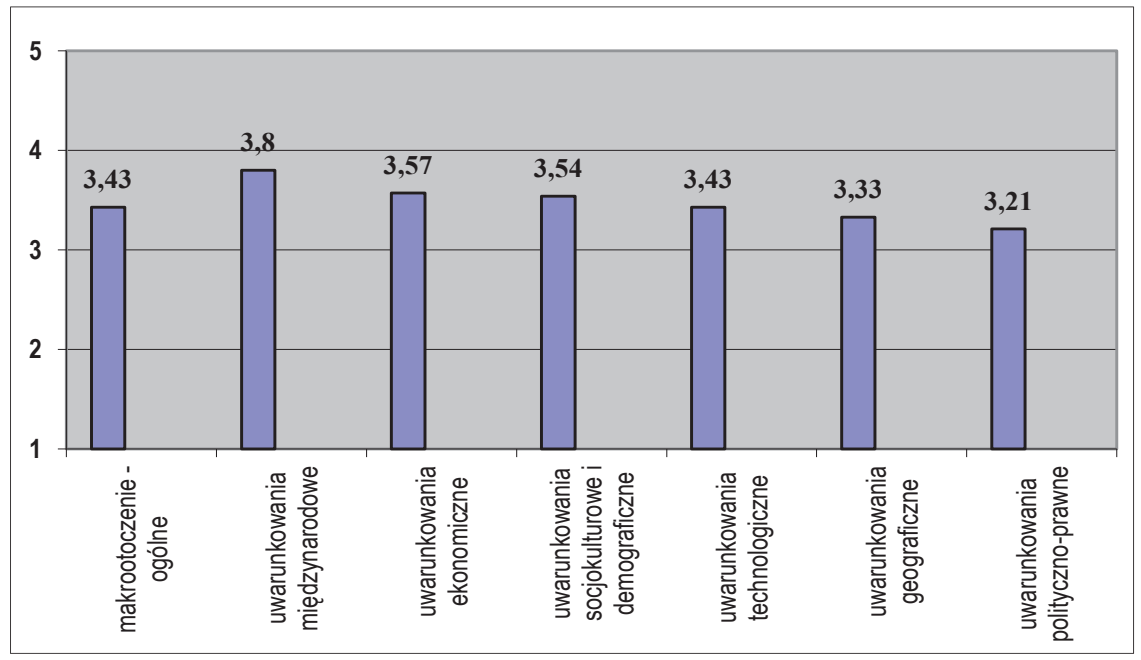

Wykres 1. Wpływ uwarunkowań makrootoczenia na budowę potencjału konkurencyjnego polskich tajemniczych mistrzów

Źródło: opracowanie własne na podstawie przeprowadzonych badań empirycznych. 
Można zatem wysunąć wniosek, że potencjał konkurencyjny polskich tajemniczych mistrzów determinowany jest raczej przez uwarunkowania wewnętrzne, a zatem przez posiadane zasoby. Uwarunkowania zewnętrzne natomiast nie wywierają znacznego wpływu na omawiany tu potencjał konkurencyjny.

\section{LITERATURA}

Bielski M., (2001), Organizacje, istota, struktury, procesy, wyd. III, Wydawnictwo Uniwersytetu Łódzkiego, Łódź

Digman L. A., (1990), Strategic Management. Concepts, Decisions, Cases, BPI Irwin, Boston.

Godziszewski B., (1999), Potencjat konkurencyjności przedsiębiorstw jako źródto przewagi konkurencyjnej i podstawa stosowanych instrumentów konkurowania, [w:] M. J. Stankiewicz (red.), Budowanie potencjału konkurencyjności przedsiębiorstwa, TNOiK, Torun.

Kaczmarczyk S., (2002), Badania marketingowe. Metody i techniki, PWE, Warszawa.

Karaszewski W., (2004), Bezpośrednie inwestycje zagraniczne. Polska na tle świata, TNOiK, „Dom Organizatora”, Torun.

Karaszewski W., (2001), Przedsiębiorstwa z udziałem kapitału zagranicznego $w$ Polsce w latach 1990-1999 (miejsce w gospodarce kraju, czynniki i perspektywy rozwoju), Wydawnictwo Uniwersytetu Mikołaja Kopernika, Toruń.

Kotler Ph., (1999), Marketing. Analiza, planowanie, wdrażanie i kontrola, Wydawnictwo Felberg, Warszawa.

Koźmiński A. K., (2005), Organizacja, [w:] A. K. Koźmiński, W. Piotrowski (red.), Zarzadzanie. Teoria i praktyka, Wydawnictwo Naukowe PWN, Warszawa.

Krzysztofiak M., Urbanek D., (1975), Metody statystyczne, PWN, Warszawa.

Simon H., Dietl M., (2009), Tajemniczy mistrzowie XXI wieku. Strategie sukcesu nieznanych liderów na światowych rynkach, Difin, Warszawa.

Stankiewicz M. J., (2002), Konkurencyjność przedsiębiorstwa. Budowanie konkurencyjności przedsiębiorstwa w warunkach globalizacji, Dom Organizatora TNOiK, Torun.

Sudolska A., (2011), Uwarunkowania budowania relacji proinnowacyjnych przez przedsiębiorstwa w Polsce, Wydawnictwo Naukowe UMK, Torun.

Zastempowski M., (2004), Czynniki otoczenia stymulujace i hamujace aktywność innowacyjna przedsiębiorstw, [w:] M. Haffer (red.), Innowacyjność 
i potrzeby proinnowacyjne regionu kujawsko-pomorskiego, Wydawnictwo UMK, Toruń.

\title{
CONSTRUCTION OF EXTERNAL CONDITIONS OF COMPETITIVE POTENTIAL OF HIDDEN CHAMPIONS OF POLISH ECONOMY
}

\begin{abstract}
A bstract: Considerations in this article refer to a specific group of companies, which are Polish hidden champions, so the company avoids publicity, and at the same time occupying leading positions in the European markets or the world. The paper presents the results of the research portion of the Polish hidden champions. The purpose of this article is to show the external factors that have the greatest impact on the construction of the competitive potential of Polish hidden champions. It seems to be an extremely important noticing the impact of macro-factors on the competitive potential of the decent imitation of a group of companies.
\end{abstract}

K e yw ord s: polish mysterious masters; the potential competitive external environment. 